\title{
Cyclization Reactions Involving 2-Aminoarenetellurols and Derivatives of $\alpha, \beta$-Unsaturated Carboxylic Acids
}

\author{
Jayna A. Patel, ${ }^{1}$ Aundrea M. Lee, ${ }^{1}$ Donna V. Franklin, ${ }^{1}$ Frank R. Fronczek, ${ }^{2}$ \\ and Thomas Junk (iD) \\ ${ }^{1}$ Department of Chemistry, University of Louisiana at Lafayette, Lafayette, LA 70507, USA \\ ${ }^{2}$ Department of Chemistry, Louisiana State University, Baton Rouge, LA 70803, USA \\ Correspondence should be addressed to Thomas Junk; txj9137@louisiana.edu
}

Received 30 September 2021; Revised 3 December 2021; Accepted 4 December 2021; Published 22 December 2021

Academic Editor: Tieqiao Chen

Copyright (c) 2021 Jayna A. Patel et al. This is an open access article distributed under the Creative Commons Attribution License, which permits unrestricted use, distribution, and reproduction in any medium, provided the original work is properly cited.

The reductive cyclization of arenetellurols carrying $\alpha, \beta$-unsaturated amide functionalities in the ortho position was investigated. Conceptually, such compounds can form 1,3-tellurazoles without the involvement of the unsaturation in the ring closure, they can form 1,4-tellurazinone derivatives, or they can undergo ring closure to 1,5-tellurazepinones. Amides derived from acrylic and methacrylic acid generated 1,5-tellurazepinones while 2-cinnamylamidobenzenetellurol cyclized to a 1,3-tellurazole derivative. In contrast, the reaction of acetylenedicarboxylic acid and its derivatives with 2-aminoarenetellurols generated 1,4-tellurazepinones, including a derivative of novel tricyclic naphtho $[1,4]$ tellurazinone. A comparison with analogous reactions of sulfur congeners indicates that their chemistry is a good predictor for the products obtained from 2-aminoarenetellurols. Selected compounds were characterized by X-ray crystallography. The present work offers access to previously unexplored organotellurium heterocycles.

\section{Introduction}

The chemistry of Te, N-containing heterocycles has found significant recent interest. This can be attributed in part due to the tendency of some members of this class to self-assemble to form supramolecular structures [1-3] and in part due to rising interest in the medicinal properties of organotellurium heterocycles as potent enzyme inhibitors [4-6] and antioxidants [7]. Sulfur congeners of the compounds targeted in this study play a central role in medicinal chemistry. 1,4-Thiazinones have been studied for their antimicrobial activity $[8,9]$, as inhibitors of alpha amylase [10] and of peptide deformylase [11], for their anti-inflammatory and analgesic properties [12] and as antifungal agents [13]. Thiazepinone derivatives such as diltiazem have a long history as antidepressants [14] and as antihypertensives $[15,16]$. They are currently under investigation for leukemia treatment [17]. Such characteristics may be enhanced in heavy chalcogen congeners due to their enhanced nucleophilicity [18], but there is a paucity of methods available for their preparation [19]. Intramolecular cyclization reactions of 2-aminoarenetellurols carrying $\alpha, \beta$-unsaturated amide functionalities offer an attractive potential option for preparing organotellurium heterocycles, but to date have remained largely unexplored. Similarly, little has been reported about cyclization reactions involving alkynes and arenetellurols.

Conceptually, arenetellurols carrying $\alpha, \beta$-unsaturated amide functionalities in an ortho position are capable of undergoing cyclization following three different pathways: to 1,3-tellurazole derivatives without the participation of the multiple bonds of the amide moiety, to derivatives of 1,4tellurazine by exo ring closure, or to 1,5-tellurazepin-4(5H)one derivatives by endo ring closure. Furthermore, such cyclizations should be feasible for both alkene and alkyne precursors and can be classified as following pathways 1 to 3, as outlined in Figure 1.

Little is known concerning the outcome of such reactions. Treatment of (2E)-N-[2-(methyltelluro) phenyl]-3-phenyl-2-propenamide and N-[2-(methyltelluro) phenyl]-3-phenyl-2-propynamide, respectively, with phosphorous oxychloride was reported to result in the formation 


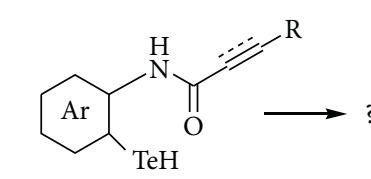

$\alpha, \beta$-unsaturated 2-acylaminoarenetellurol

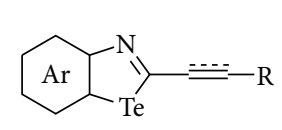

1,3-tellurazole Pathway 1

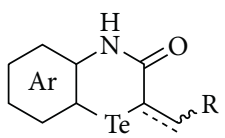

1,4-tellurazinone Pathway 2

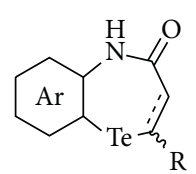

1,5-tellurazepinone Pathway 3

Figure 1: Potential pathways for the cyclization of arenetellurols carrying $\alpha, \beta$-unsaturated amide functionalities in the ortho position.

of 1,3-tellurazole derivatives, essentially following pathway 1 as shown in Figure $2[5,6]$.

In contrast, treatment of bis(2-amino-3,5-dimethyl) ditelluride with dimethyl acetylenedicarboxylate in the presence of hypophosphorous acid as a reducing agent was reported to generate methyl (Z)-2-(5,7-dimethyl-3-oxo-3,4dihydro-2H-benzo[b] [1, 4]tellurazin-2-ylidene)acetate as shown in Figure 3, thereby following pathway 2 [20]. This is equivalent to cyclizations reported for the reaction of the sulfur congener 2-aminobenzenethiol with dimethylacetylene dicarboxylate, which consistently generated $2 \mathrm{H}-1,4-$ benzothiazine derivatives $[8,9]$. This result is remarkable since an earlier study that investigated Michael-type ring closures of propynoic amides of 2-aminobenzenetellurol concluded that they exclusively follow pathway 3 and generate 1,5-tellurazepinones via 7-endo-dig ring closure [21]. No other examples of this reaction type have been published.

All three modes of cyclization are known for sulfur congeners, as exemplified by the condensation of 2-aminobenzenethiol with cinnamic acid to (E)-2-(2-phenylethenyl) benzothiazole [22], that of 2-aminobenzenethiol with maleic anhydride to 2-(3,4-dihydro-3-oxo-2H-1,4-benzothiazin-2ylidene)acetic acid [10], and that of 2-aminobenzenethiol with cinnamic acid to 2,3-dihydro-2-phenyl-1,5-benzothiazepin$4(5 \mathrm{H})$-one [23]. These reactions represent sulfur equivalents of pathways 1,2, and 3 as shown in Figure 1. The only relevant published selenium equivalent is the cyclization of (2E)-N-[2(methylseleno)phenyl]-3-phenyl-2-propenamide to 2-[(1E)2-phenylethenyl]-1,3-selenazole, which follows pathway 1 [24]. The present study aims to evaluate cyclizations of selected 2-aminoarenetellurols with derivatives of $\alpha, \beta$-unsaturated carboxylic acids by tandem amidation-addition and compare them to published data for sulfur congeners, with the objectives of improving synthetic access to organotellurium heterocycles and determining whether sulfur congeners are good predictors of the products derived from 2 aminoarenetellurols.

\section{Materials and Methods}

Bis(2-aminophenyl) ditelluride was prepared as previously reported [25]. 3-Chloro-3H-naphth [2,1-c] [1,2,5] oxatellurazole was prepared according to the patent literature [26]. All other chemicals were purchased as reagent grade and used as received. Silica gel, $40-65 \mu \mathrm{m}$, obtained from VWR, was used for flash chromatography. Melting points were recorded in open capillaries using an electrothermal SRS MPA160 apparatus and are not corrected. Nuclear magnetic resonance spectra were recorded on a Varian MR $400 \mathrm{MHz}$ NMR spectrometer. High-resolution mass spectra were recorded on an Agilent 6230 ESI TOF mass spectrometer in the positive mode, except for $\mathbf{6}$, which was recorded in the negative mode. Peaks in the molecular cluster exceeding $10 \%$ of base were reported. Infrared spectra were recorded for pure solids with a Jasco FTIR-4700 spectrometer. UV irradiation was carried out with a Rayonet RPR-200 photochemical reactor. Caution: due to the generation of trace amounts of hydrogen telluride and volatile organotellurium compounds, all operations should be carried out under a well-vented hood. The target products are summarized in Figure 4.

2.1. 2,3-Dihydrobenzo[b] [1,4]tellurazepin-4(5H)-one (1). A $25 \mathrm{~mL}$ round-bottom flask with magnetic stirring was charged with bis(2-aminophenyl) ditelluride (132 mg, $0.30 \mathrm{mmol}$ ), dissolved in $5 \mathrm{~mL}$ of tetrahydrofuran (THF). Acrylic anhydride $(76 \mathrm{mg}, 60 \mathrm{mmol}$ ) was then added. The mixture was stirred and heated to reflux for $1 \mathrm{~min}$ to assure amide formation. After cooling to room temperature, excess hypophosphorous acid (48\%, $138 \mathrm{mg}, 1.0 \mathrm{mmol})$ was added and the mixture stirred for $4 \mathrm{hrs}$, at which time the orange color had faded significantly. The mixture was then heated to reflux for $20 \mathrm{~min}$. Subsequently, it was placed in an open beaker under the hood and volatiles were allowed to evaporate. The residue was diluted with $3 \mathrm{~mL}$ of water and neutralized with saturated sodium bicarbonate solution. The product was extracted with $2 \times 5 \mathrm{~mL}$ of $\mathrm{CHCl}_{3}$, and the extract was freed of highly polar impurities by flash chromatography through a $1 \times 3 \mathrm{~cm}$ column (silica gel, $\mathrm{CHCl}_{3}$ ) and allowed to evaporate in an open beaker. The residue was recrystallized twice from ethanol. Off-white crystals, yield $33 \%, \mathrm{mp} 223-225^{\circ} \mathrm{C}$. The product has a tendency to turn brown over time. IR $\left(\mathrm{cm}^{-1}\right): 3055,1626,1465,1223$, and 745 . ${ }^{1} \mathrm{HNMR}\left(\mathrm{CDCl}_{3}\right): \delta=2.76(\mathrm{t}, J=6.7 \mathrm{~Hz}, 2 \mathrm{H}) ; 3.51 \quad(\mathrm{t}$, $J=6.7 \mathrm{~Hz}, 2 \mathrm{H}) ; 7.06(\mathrm{t}, J=6.7 \mathrm{~Hz}, 1 \mathrm{H}) ; 7.13(\mathrm{~d}, J=6.7 \mathrm{~Hz}, 1$ $\mathrm{H})$; $7.39(\mathrm{~J}=6.7 \mathrm{~Hz}, 1 \mathrm{H})$; $7.88(\mathrm{~N}-\mathrm{H})$; and $7.92(\mathrm{~d}, 1 \mathrm{H}) .{ }^{13} \mathrm{C}$ $\operatorname{NMR}\left(\mathrm{CDCl}_{3}\right): \delta=2.52,34.15,109.69$, and 174.33. TOF ES+, $\left(\mathrm{M}^{+}+1\right), \mathrm{mz}(\%): 271.9728$ (21), 272.9796 (20), 273.9772 (65), 275.9791 (100), 276.9811 (10), and 277.9825 (90). Calcd for $\mathrm{C}_{9} \mathrm{H}_{9} \mathrm{NOTe}$ : C 39.34, H 3.30, and N 5.10; found: C 39.33, $\mathrm{H} 3.33$, and N 5.03.

2.2. (R,S)-3-Methyl-2,3-dihydrobenzo[b] [1, 4]tellurazepin4(5H)-one (2). A $25 \mathrm{~mL}$ round-bottom flask with magnetic stirring was charged with bis(2-aminophenyl) ditelluride (132 mg, $0.30 \mathrm{mmol}$ ) dissolved in $1 \mathrm{~mL}$ of THF. Methacrylic 

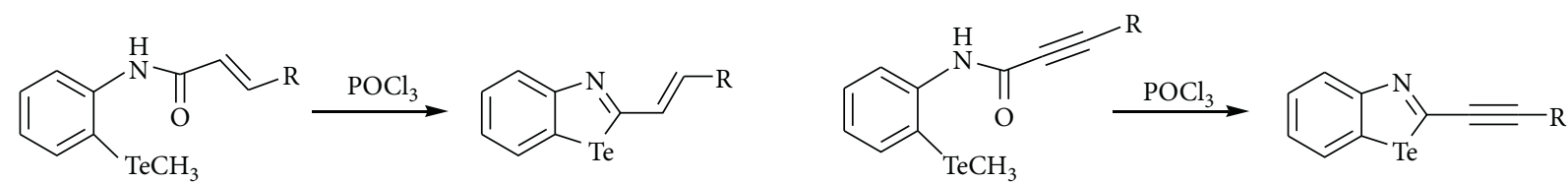

Figure 2: Previously reported cyclizations of benzenetelluroles carrying $\alpha, \beta$-unsaturated amide functionalities; $R=$ phenyl.<smiles>COC(=O)/C=C1\[Te]c2cc(C)cc(C)c2NC1=O</smiles>

Figure 3: Previously reported preparation of methyl (Z)-2-(5,7-dimethyl-3-oxo-3,4-dihydro-2(H)-benzo[b] [1, 4]tellurazin-2-ylidene) acetate.
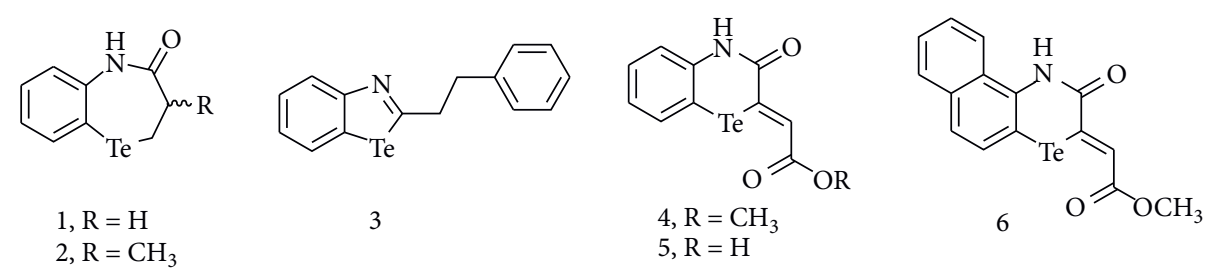

FIgURE 4: Products prepared in this study.

anhydride (92.5 mg, $0.6 \mathrm{mmol}$ ) was added. The mixture was stirred and heated to reflux for $1 \mathrm{~min}$ to assure amide formation. Ethanol (95\%, $4 \mathrm{~mL}$ ) was added, followed by excess hypophosphorous acid $(48 \%, 138 \mathrm{mg}, 1.0 \mathrm{mmol})$, and the mixture was stirred for $1 \mathrm{hr}$. The orange color faded significantly during this time. The mixture was subsequently heated to reflux for $1 \mathrm{hr}$, at which time it was near-colorless. It was placed in an open beaker under the hood, volatiles were allowed to evaporate, and it was further processed like 1, colorless crystals, yield $41 \%, \mathrm{mp} 202-204^{\circ} \mathrm{C}$. The product has a tendency to turn grey due to photodecomposition and was stored in a refrigerator. IR $\left(\mathrm{cm}^{-1}\right): 2921,1654,1416$, 1271, 759, and 726. ${ }^{1} \mathrm{HNMR}\left(\mathrm{CDCl}_{3}\right): \delta=1.23(\mathrm{~d}, J=6.4 \mathrm{~Hz}$, $3 \mathrm{H}) ; 2.68(\mathrm{~m}, 1 \mathrm{H}) ; 3.05$ (d of d's, ${ }^{2} J=9.8 \mathrm{~Hz},{ }^{3} J=4.7 \mathrm{~Hz}$, $1 \mathrm{H}) ; 3.57(\mathrm{~m}, 1 \mathrm{H}) ; 7.05(\mathrm{t}, J=7.4 \mathrm{~Hz}, 1 \mathrm{H}) ; 7.14(\mathrm{~d}$, $J=3.8 \mathrm{~Hz}, 1 \mathrm{H}) ; 7.38(\mathrm{t}, J=8.2 \mathrm{~Hz}, 1 \mathrm{H}) ; 7.90(\mathrm{~d}, J=7.4 \mathrm{~Hz}$, $1 \mathrm{H})$; and $7.99(\mathrm{~N}-\mathrm{H}) .{ }^{13} \mathrm{C} \mathrm{NMR}\left(\mathrm{CDCl}_{3}\right): \delta=10.00,18.65$, $36.94,110.45,123.89,126.85,130.13,140.34,142.73$, and 176.69. TOF ES+, $\left(\mathrm{M}^{+}+1\right), \mathrm{mz}(\%): 285.9935$ (13), 286.9955 (21), 287.9945 (56), 289.9960 (93), 291.9979 (100), and 293.0002 (10). Calcd for $\mathrm{C}_{10} \mathrm{H}_{11}$ NOTe: $\mathrm{C} 41.49$, H 3.84, and $\mathrm{N} 4.85$; found: C 41.63, H 3.84, and $\mathrm{N} 4.84$.

2.3. 2-(2-Phenylethyl)benzo-1,3-tellurazole (3). A $50 \mathrm{~mL}$ round-bottom flask with magnetic stirring was charged with bis(2-aminophenyl) ditelluride (132 $\mathrm{mg}, 0.30 \mathrm{mmol})$ and pyridine $(48 \mathrm{mg}, 61 \mathrm{mmol})$, dissolved in $2 \mathrm{~mL}$ of THF. Cinnamyl chloride $(100 \mathrm{mg}, 0.6 \mathrm{mmol}$ ) was added, and the mixture stirred for $10 \mathrm{~min}$ to complete amide formation. After dilution with methanol $(95 \%, 4 \mathrm{~mL})$ and addition of excess hypophosphorous acid (48\%, $207 \mathrm{mg}, 1.5 \mathrm{mmol})$, the mixture was heated to reflux with stirring for $6 \mathrm{hrs}$. The color changed from orange to yellow. The crude product mixture was diluted with $5 \mathrm{~mL}$ of water, neutralized with conc. sodium bicarbonate solution, and extracted with $2 \times 4 \mathrm{~mL}$ dichloromethane (DCM). Solvents were allowed to evaporate, and the residue was extracted with $2 \times 5 \mathrm{~mL}$ of hot heptane. The solvent was then removed by rotary evaporation. For further purification, the product was dissolved in ethanol $(20 \mathrm{ml}$, $95 \%$ ) at $60^{\circ} \mathrm{C}$, placed in a $100 \mathrm{~mL}$ round-bottom quartz flask, and irradiated with UV light in a photoreactor for 4 hrs in the presence of air. This oxidized traces of persistent orange impurities (likely ditellurides) while leaving the product unaltered. Further purification by flash chromatography (hexane:silica gel) and recrystallization from methanol furnished the product, pale yellow needles, yield $61 \%, \mathrm{mp}$ 135-137 ${ }^{\circ} \mathrm{C}$. IR $\left(\mathrm{cm}^{-1}\right): 3041,1515,1496,757$, and 691. ${ }^{1} \mathrm{HNMR}$ $\left(\mathrm{CDCl}_{3}\right): \delta=3.14(\mathrm{t}, J=7.4 \mathrm{~Hz}, 2 \mathrm{H}) ; 3.40(\mathrm{t}, J=7.4 \mathrm{~Hz}, 2 \mathrm{H})$; $7.14(\mathrm{t}, J=7.8 \mathrm{~Hz}, 1 \mathrm{H}) ; 7.23-7.32(\mathrm{~m}, 5 \mathrm{H}) ; 7.44(\mathrm{t}, J=7.0 \mathrm{~Hz}$, $1 \mathrm{H}) ; 7.84(\mathrm{~d}, J=7.8 \mathrm{~Hz}, 1 \mathrm{H})$; and $7.90(\mathrm{~d}, J=7.0 \mathrm{~Hz}, 1 \mathrm{H}) \cdot{ }^{13} \mathrm{C}$ NMR $\left(\mathrm{CDCl}_{3}\right): \delta=36.10,44.56,124.73,125.64,126.56$, $126.72,128.62,128.68,131.56,134.38,139.63,159.99$, and 176.58. ES+, $\left(\mathrm{M}^{+}+1\right), \mathrm{mz}(\%): 332.0147$ (16), 333.0177 (23), 334.0158 (61), 336.0167 (95), 337.0205 (16), 338.0188 (100), and 339.0226 (16); Calcd for $\mathrm{C}_{15} \mathrm{H}_{13} \mathrm{NTe}$ : C 50.80, H 3.91, and $\mathrm{N}$ 4.18; found: C 50.84, H 4.05, and N 4.15.

2.4. Methyl (Z)-2-(5,7-dimethyl-3-oxo-3,4-dihydro-2H-benzo [b] [1, 4]tellurazin-2-ylidene)acetate (4). A $50 \mathrm{~mL}$ roundbottom flask with magnetic stirring was charged with bis(2- 
aminophenyl) ditelluride (132 mg, $0.30 \mathrm{mmol})$, dimethyl acetylenedicarboxylate $(100 \mathrm{mg}, 0.66 \mathrm{mmol})$, and $1 \mathrm{~mL}$ of THF. The resulting solution was diluted with ethanol (95\%, $3 \mathrm{~mL}$ ), followed by addition of hypophosphorous acid (48\%, $138 \mathrm{mg}, 1.0 \mathrm{mmol}$ ). The mixture was set aside for $3 \mathrm{hrs}$ and then concentrated to approx. $50 \%$ of its original volume. The resulting orange crystals were collected by filtration, dissolved in $5 \mathrm{~mL}$ THF, centrifuged to remove traces of elemental tellurium, diluted with ethanol $(4 \mathrm{~mL}, 95 \%)$, and concentrated to approx. $3 \mathrm{~mL}$, thereby removing the THF and causing the product to precipitate. The product was collected by filtration, orange crystals, yield $42 \%, \mathrm{mp}$ $286-288^{\circ} \mathrm{C}$. IR $\left(\mathrm{cm}^{-1}\right): 3020,1635,1537,1368,1303,1178$, and 744. ${ }^{1} \mathrm{HNMR}\left(\mathrm{CD}_{3} \mathrm{SOCD}_{3}\right): \delta=3.82(\mathrm{~s}, 3 \mathrm{H}) ; 6.94-7.02$ $(\mathrm{m}, 1 \mathrm{H}) ; 7.75(\mathrm{~d}, J=7.4 \mathrm{~Hz}, 1 \mathrm{H})$; and $8.03(\mathrm{~s}, 1 \mathrm{H}) .{ }^{13} \mathrm{C} \mathrm{NMR}$ $\left(\mathrm{CD}_{3} \mathrm{SOCD}_{3}\right): \delta=52.61,103.22,118.88,123.22,123.66$, $127.79,132.40,135.75,139.07,156.02$, and 169.38. ES+, $\left(\mathrm{M}^{+}+1\right), \mathrm{mz}(\%): 327.9670$ (14), 328.9690 (21), 329.96855$)$, 331.9696 (85), 332.972 (13), 333.9711 (100), and 334.9741 (13). Calcd for $\mathrm{C}_{11} \mathrm{H}_{9} \mathrm{NO}_{3} \mathrm{Te}$ : $\mathrm{C} 39.94, \mathrm{H} 2.74$, and $\mathrm{N}$ 4.23; found: C 40.09, $\mathrm{H} 2.58$, and $\mathrm{N} 4.22$.

2.5. (Z)-2-(3-oxo-3,4-dihydro-2H-benzo[b] [1,4]tellurazin-2ylidene)acetic acid (5). A $50 \mathrm{~mL}$ round-bottom flask was charged with bis(2-aminophenyl) ditelluride (132 mg, $0.3 \mathrm{mmol})$, acetylene dicarboxylic acid $(26 \mathrm{mg})$, and THF $(4 \mathrm{~mL})$. After $2 \mathrm{~min}$, most material had gone into the solution. Excess hypophosphorous acid was then added (48\%, $138 \mathrm{mg}, 1.0 \mathrm{mmol}$ ). The mixture was stirred for $2 \mathrm{hrs}$, then heated to reflux for $1 \mathrm{hr}$, and finally, allowed to cool to ambient temperature. The solution was centrifuged to remove solid impurities, diluted with an equal amount by volume of 1-propanol, and set aside for open air evaporation. After the volume had decreased to approx. 1/2 of its original value, the separated crystals were washed with $1 \mathrm{~mL}$ of ice cold ethanol and collected, red crystals, yield 19\%, mp $292-293^{\circ} \mathrm{C}$. The compound has a tendency to decompose over time and was refrigerated for storage. IR $\left(\mathrm{cm}^{-1}\right): 2955$, $1634,1527,1418,1284$, and $1231 .{ }^{1} \mathrm{HNMR}\left(\mathrm{CD}_{3} \mathrm{SOCD}_{3}\right)$ : $\delta=6.96-6.98(\mathrm{~m}, 1 \mathrm{H}) ; 7.20-7.21(\mathrm{~m}, 2 \mathrm{H}) ; 7.70(\mathrm{~d}, J=7.4$, $1 \mathrm{H})$; and $7.03(\mathrm{~s}, 1 \mathrm{H}){ }^{13} \mathrm{C} \mathrm{NMR}\left(\mathrm{CD}_{3} \mathrm{SOCD}_{3}\right): \delta=104.26$, $118.75,123.13,124.92,127.62,132.31,135.26,139.14,156.32$, and 170.42. ES+, $\left(\mathrm{M}^{+}+1\right), \mathrm{mz}(\%): 308.9943(33), 313.95226$ (16), 314.9531 (25), 315.9545 (60), 317.9560 (96), 319.9609 (100), 320.9881 (22), and 321.9968 (50). Calcd for $\mathrm{C}_{10} \mathrm{H}_{7} \mathrm{NO}_{3} \mathrm{Te}: \mathrm{C} 37.92, \mathrm{H} 2.23$, and N 4.42; found: C 38.10, H 2.24, and N 4.28 .

2.6. Methyl (Z)-2-(2-oxo-1,2-dihydro-3H-naphtho[2,1-b] [1,4]tellurazin-3-ylidene)acetate (6). A $50 \mathrm{~mL}$ round-bottom flask was charged with 3 -chloro-3H-naphtho [2,1-c] $[1,2,5]$ oxatellurazole $(160 \mathrm{mg}, 0.5 \mathrm{mmol})$ and THF $(2 \mathrm{~mL})$. The resulting solution was diluted with ethanol $(95 \%, 4 \mathrm{~mL})$. A reflux condenser was fitted, and the mixture purged with nitrogen. Sodium borohydride was subsequently added in small portions with stirring until the intense magenta color of the oxatellurazole had given way to the brownish yellow color of 1-aminonaphthalenetellurol (approx. $160 \mathrm{mg}$ consumed). Dimethyl acetylenedicarboxylate (78 mg, $0.55 \mathrm{mmol}$ ) was subsequently added, followed by excess hypophosphorous acid $(48 \%, 207 \mathrm{mg}, 1.5 \mathrm{mmol})$ to create an acidic and highly reducing environment. The mixture was subsequently heated to reflux for $10 \mathrm{~min}$ and then transferred to a beaker, and volatiles were allowed to evaporate overnight under a hood. The residue was diluted with $5 \mathrm{~mL}$ of water, and the black-orange solid material was collected by filtration. It was washed with an additional $3 \mathrm{~mL}$ of water and air-dried. The crude product was taken up in $10 \mathrm{~mL}$ of THF and solids (mostly extremely fine tellurium particles) removed by centrifugation. The volume of the solution was reduced to approx. $3 \mathrm{~mL}$ by rotary evaporation, the mixture was cooled, and the resulting orange solid was collected. For further purification, it was recrystallized from chlorobenzene, orange crystals, yield $36 \%, \mathrm{mp} 276-278^{\circ} \mathrm{C}$. IR $\left(\mathrm{cm}^{-1}\right)$ : $3243,1633,1533,1291$, and 1176. ${ }^{1} \mathrm{HNMR}\left(\mathrm{CD}_{3} \mathrm{SOCD}_{3}\right)$ : $\delta=3.84(\mathrm{~s}, 3 \mathrm{H}) ; 7.53-7.59(\mathrm{~m}, 3 \mathrm{H}) ; 7.80(\mathrm{~d}, J=8.6 \mathrm{~Hz}, 1 \mathrm{H})$; $7.91(\mathrm{~d}, J=7.5,1 \mathrm{H}) ; 8.07(\mathrm{~s}, 1 \mathrm{H}) ; 8.50(\mathrm{~d}, J=7.8 \mathrm{~Hz}, 1 \mathrm{H})$, and $10.69(\mathrm{~N}-\mathrm{H}) .{ }^{13} \mathrm{C}$ NMR $\left(\mathrm{CD}_{3} \mathrm{SOCD}_{3}\right): \delta=52.69,101.24$, $120.53,123.15,123.86,124.01,126.18,126.34,128.29,129.19$, 132.81, 133.30, 135.85, 157.51, and 169.38. $\left(\mathrm{M}^{-}-1\right), \mathrm{mz}(\%)$ : 375.9636 (17), 376.9717 (23), 377.9695 (52), 379.9616 (100), 380.9733 (17), 381.9714 (93), and 382.9762 (15). Calcd for $\mathrm{C}_{15} \mathrm{H}_{11} \mathrm{NO}_{3}$ Te: $\mathrm{C} 47.51, \mathrm{H} 2.91$, and $\mathrm{N} 3.69$; found: $\mathrm{C} 47.80$, $\mathrm{H} 3.17$, and $\mathrm{N} 3.55$.

\section{Results and Discussion}

The extreme air sensitivity of tellurols made it necessary to generate them in situ, by reduction of the corresponding ditellurides. Several attempts were made to reduce 3-chloro$3 \mathrm{H}$-naphtho $[2,1-\mathrm{c}][1,2,5]$ oxatellurazole, which is readily available from $\alpha$-tetralone and tellurium dioxide [26] to bis(1-aminonaphthyl) ditelluride and to isolate this compound as an intermediate. However, rapid expulsion of elemental tellurium was observed during attempted purification. The observed reactions closely resemble those reported for sulfur congeners, indicating that they are good predictors of cyclization behavior. The primary reason for the modest yields obtained during the preparation of 1,5tellurazepinones appears to be that the rate of ring closure is comparable to that of amide hydrolysis, resulting in the formation of 2-aminophenyltelluropropanoic acid derivatives. In contrast, ring closures involving 2-aminobenzenetellurol were yield limited largely by the tendency of this compound to undergo tellurium expulsion under acidic conditions. Attempts to achieve ring closure under neutral or basic conditions were unsuccessful.

3.1. Cyclization of Arenetellurols Carrying $\alpha, \beta$-Unsaturated Amide Moieties on the Ortho Position. The amides derived from bis(2-aminophenyl) ditelluride and acrylic or methacrylic acid underwent reductive cyclization to the corresponding 1,5-tellurazepinones without concurrent formation of 1,3-tellurazols or 1,4-tellurazinones derived from pathways 1 or 2 as defined in Figure 1. This constitutes only the second synthetic approach to 2,3-dihydro-1,5- 


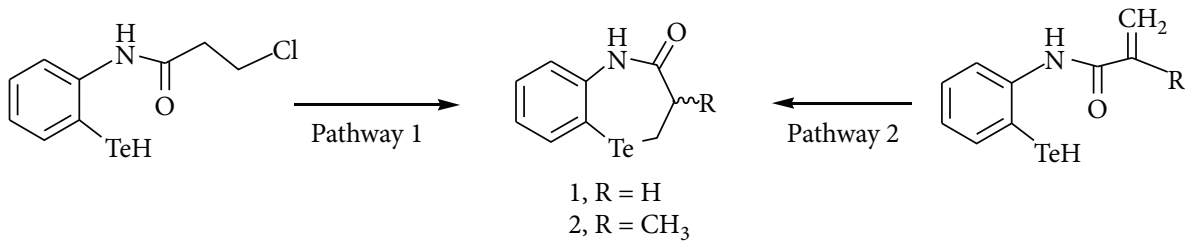

Figure 5: Access to 1,5-tellurazepinones by intramolecular $\mathrm{S}_{\mathrm{N}} 2$ substitution (pathway $1, R=(\mathrm{H})$ ) or by endo-trig ring closure (pathway 2, $\mathrm{R}=\mathrm{H}$ or $\mathrm{CH}_{3}$ ).

benzotellurazepin-4(5H)-one. Previously, 1 had been prepared by reductive cyclization of the condensation product of bis(2-aminophenyl) ditelluride and 3-chloropropanoyl chloride [27] (Figure 5).

An ORTEP plot of 2 (Figure 6) shows that the heterocyclic ring adopts a twist boat conformation and is strongly bent along the $\mathrm{N}$-Te axis. As a result, the mean standard deviation from planarity for all carbons and heteroatoms contained in the bicyclic ring system is $0.524 \AA$. This shape is similar to that previously reported for 2,3-dihydro-1,5benzoellurazepin-4(5H)-one [27] and for a similar sulfur analog, 7-bromo-3,3-dibutyl-8-methoxy-2,3-dihydro-1,5benzothiazepin-4(5H)-one [28]. The Te-C1 bond length of $2.1642(9) \AA$ found for this compound is somewhat longer than 2.109(4) $\AA$ found for the equivalent bond of $2 \mathrm{H}-1,4$ benzotellurazin-3 $(4 \mathrm{H})$-one [27]. In the crystalline state, hydrogen bonding exists between the amide nitrogen and the carbonyl oxygen on adjacent molecules, but no supramolecular assembly mediated by secondary Te-N bonding is formed, in contrast to those observed for 1,3-tellurazoles $[5,17]$.

1,5-Tellurazepinones are moderately sensitive to air and light in solution, making their purification somewhat challenging. The attempted cyclization of 2-aminobenzenetellurol with atropic acid resulted in complex product mixtures. To date, no example of an exo-trig cyclization involving a 2-aminoarenetellurol and an alkene, equivalent to the synthesis of 2-(3,4-dihydro-3-oxo- $2 \mathrm{H}-1,4$ benzothiazin-2-ylidene)acetic acid from 2-aminobenzenethiol and maleic anhydride, has been encountered.

In contrast to amides derived from acrylic and methacrylic acid, those derived from trans-cinnamic acid followed pathway 1 . Thus, the reductive cyclization of (E,E)-2,2' - [(1-oxo-3-phenyl-2-propenyl) aminophenyl] ditelluride, prepared from bis(2-aminophenyl) ditelluride and cinnamyl chloride in a one-pot procedure, furnished 3 as shown in Figure 7. The product of this reaction is comparable to that previously reported for the reaction of (2E)-N-[2-(methyltelluro)phenyl]-3-phenyl-2-propenamide with phosphorous oxychloride [29], with the notable difference that the exocyclic double bond was reduced under the chosen conditions. GC-MS analysis of the crude product mixture, sampled during cyclization, strongly suggests the intermediacy of 2-[(1E)-2-phenylethenyl]1,3-benzotellurazole, discounting the notion that the tellurazepinone is not formed because the cinnamyl double bond is reduced before ring closure. There was no indication for the formation of the corresponding 1,4tellurazinone (following pathway 2) or 1,5-

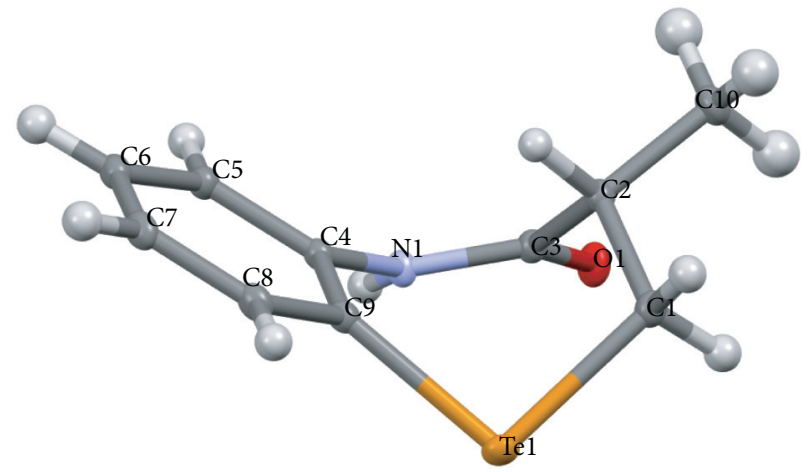

FIGURE 6: ORTEP plot of 3-methyl-2,3-dihydro-1,5-benzotellurazepin-4(5H)-one 2.

tellurazepinone (following pathway 3 ). It is probable that the reason for the exclusion of the cinnamyl double bond from the cyclization is a result of its enhanced stability due to extended conjugation.

In practice, small quantities of intensely pink-colored organotellurium byproducts (likely ditellurides) were obtained during the synthesis of 2-(2-phenylethyl)benzo-1,3tellurazole, from which it is difficult to separate. These impurities could be oxidatively removed by illumination with ultraviolet light in the presence of air. This affirms the very high photostability of benzo-1,3-tellurazole derivatives.

3.2. Cyclization of Arenetellurols with Acetylene Dicarboxylic Acid and Its Methyl Ester. Reactions of acetylene dicarboxylic acid and its dimethyl ester with 2-aminoarenetellurols consistently resulted in exo-dig cyclizations. Such cyclizations generate areno-1,4-tellurazinone derivatives, as shown in Figure 8. It should be noted that the products are formed by stereospecific antiaddition (Figure 9), in contrast to equivalent reactions employing 2aminobenzenethiols, which have been reported to occur syn or antidepending on the reaction conditions $[9,11]$. It is noteworthy that phenylpropynoic acid did not give rise to any cyclization products.

The condensation of dimethyl acetylene dicarboxylate with 1-aminonaphthene-2-tellurol, prepared in situ by reduction of 3-chloro-3H-naphth[2,1-c][1,2,5] oxatellurazole, resulted in novel tricyclic methyl (Z)-2-(2-oxo-1,2-dihydro$3 H$-naphtho[2,1-b] $[1,4]$ tellurazin-3-ylidene)acetate as shown in Figure 8. An ORTEP plot of this compound is shown in Figure 10.

A comparison of the products reported here to those shown in Figure 2 is in order. It appears that the outcome of 


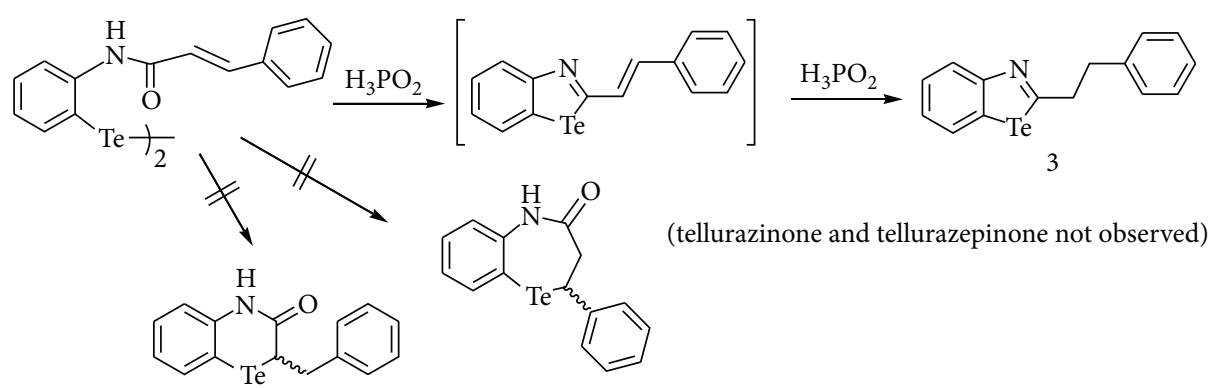

Figure 7: Reductive cyclization of (E,E)-2,2'-[(1-oxo-3-phenyl-2-propenyl)aminophenyl] ditelluride.<smiles>Nc1c(Br)ccc2ccccc12</smiles><smiles>CCOC(=O)C#CC(=O)O</smiles><smiles>CCOCC</smiles><smiles>O=C(O)/C=C1\[Te]c2ccc3ccccc3c2NC1=O</smiles>

FIGURE 8: Access to 1,5-tellurazepinones by tandem aminolysis/exo-dig addition (benzene derived: $R=(\mathrm{H}) \mathrm{CH}_{3}$; naphthalene derived: $\left.\mathrm{R}=\mathrm{CH}_{3}\right)$.

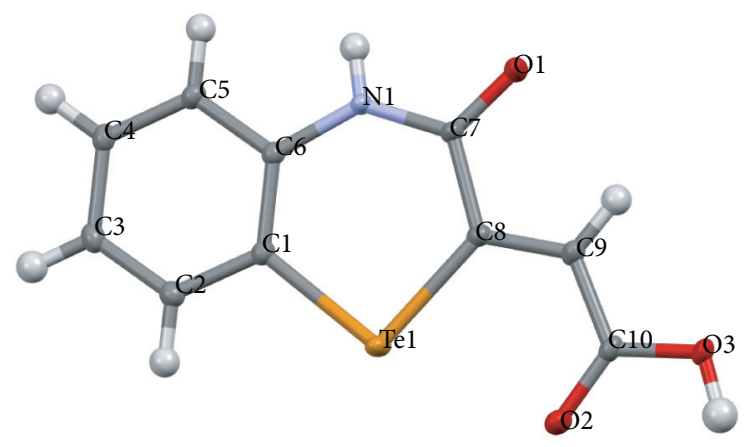

Figure 9: ORTEP plot of (Z)-2-(3-oxo-3,4-dihydro-2(H)-benzo $[(b)][1,4]$ tellurazin-2-ylidene)acetic acid 5.

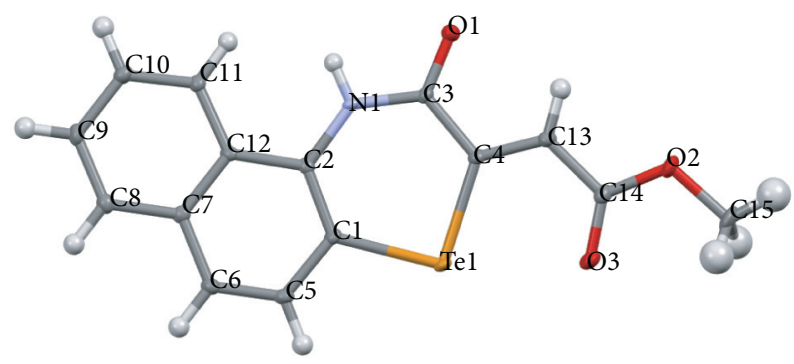

Figure 10: ORTEP plot of methyl (Z)-2-(2-oxo-1,2-dihydro-3(H)naphtho[2,1-(b)] [1, 4]tellurazin-3-ylidene)acetate 6 .

reactions involving alkynes depends on whether ring closure is carried out intermolecularly, resulting in an addition to the triple bond prior to amide bond formation, or intramolecularly, by establishing the amide moiety first. While the sequence of addition vs. aminolysis during intermolecular cyclization could not be determined with certainty in this study, the relatively rapid disappearance of the tellurol moiety strongly suggests that its addition to the triple bond precedes ring closure by amide formation. This is further supported by the cyclization of a series of 2-iodopropiolanilides with sodium hydrogen telluride, which resulted exclusively in the formation of azepinones by endo-dig cyclization rather than producing the products observed in this study [21]. X-ray analysis of compounds 2, 5, and 6 indicated the presence of hydrogen bounded dimers rather than supramolecular assemblies.

\section{Conclusions}

The reductive cyclization of arenetellurols carrying $\alpha, \beta$-unsaturated amide moieties in ortho positions was shown to provide a convenient route of access to novel Te, $\mathrm{N}$ containing heterocycles. Acrylic amides yielded 1,5-azepiones, while 1,4-tellurazinones were accessible from tandem addition/ aminolysis using alkyne precursors. Uniquely, the cyclization of a cinnamic amide resulted in the formation of a 1,3-tellurazole derivative, leaving the double bond intact. A comparison with analogous reactions of sulfur congeners indicates that their chemistry is a good predictor for the products obtained from 2aminoarenetellurols and unsaturated carboxylic acids.

\section{Data Availability}

The structures of compounds 2, 5, and 6 were deposited with the Cambridge Crystallographic Data Centre, CCDC \#1865829, 2111615, and 1922381. Mass spectral data and elemental analyses are included within the article. ${ }^{1} \mathrm{H}$ and ${ }^{13} \mathrm{C}$ NMR data are provided as a supplementary file.

\section{Conflicts of Interest}

The authors declare that there are no conflicts of interest regarding the publication of this paper. 


\section{Acknowledgments}

The authors express their gratitude to Professor August Gallo for insightful discussions and assistance during the interpretation of spectral data. This work was supported by the Department of Chemistry, University of Louisiana at Lafayette, and by the Louisiana Board of Regents (LEQSF(2011-12)-ENH-TR-01).

\section{Supplementary Materials}

${ }^{1} \mathrm{H}$ NMR and ${ }^{13} \mathrm{C}$ NMR spectra of compounds prepared in this study are available as a supplementary file. (Supplementary Materials)

\section{References}

[1] P. C. Ho, P. Szydlowski, J. Sinclair et al., "Supramolecular macrocycles reversibly assembled by Te...O chalcogen bonding," Nature Communications, vol. 7, no. 1, p. 11299, 2016.

[2] P. C. Ho, L. M. Lee, H. Jenkins, J. F. Britten, and I. VargasBaca, "Influence of acidic media on the supramolecular aggregation of iso-tellurazole N-oxides," Canadian Journal of Chemistry, vol. 94, no. 5, pp. 453-457, 2016.

[3] J. Kübel, P. J. Elder, H. A. Jenkins, I. Vargas-Baca, and I. Vargas-Baca, "Structure and formation of the first (-O-TeN-)4 ring," Dalton Transactions, vol. 39, no. 46, pp. 11126-11128, 2010.

[4] M. Brodsky, S. Yosef, R. Galit et al., "The synthetic tellurium compound, AS101, is a novel inhibitor of IL- $1 \beta$ Converting enzyme," Journal of Interferon and Cytokine Research, vol. 27, no. 6, pp. 453-462, 2007.

[5] L. A. Ba, M. Döring, V. Jamier, and C. Jacob, "Tellurium: an element with great biological potency and potential," Organic and Biomolecular Chemistry, vol. 8, no. 19, pp. 4203-4216, 2010.

[6] N. K. Klichkhanov, A. M. Dzhafarova, P. A. Ramazanova, A. M. M. Ali, G. M. Abakarov, and M. M. Dzharaeva, "A new tellurium- and selenoorganic compound as an inhibitor of acetylcholinesterase in brain," Bulletin of Experimental Biology and Medicine, vol. 168, no. 2, pp. 229-232, 2019.

[7] W. Liu, H. Min, X. Zhu, G. Deng, and Y. Liang, "Copper-catalyzed highly selective synthesis of 2-benzyl- and 2-benzylidenesubstituted benzo[b]thiazinones from 2-iodophenylcinnamamides and potassium sulfide," Organic and Biomolecular Chemistry, vol. 15, no. 46, pp. 9804-9808, 2017.

[8] V. V. Dabholkar and R. P. Gavande, "Synthesis and antimicrobial activities of novel 1,4-benzothiazine derivatives," Arabian Journal of Chemistry, vol. 9, pp. S225-S229, 2016.

[9] N. K. Sebbar, M. E. M. Mekhzoum, E. M. Essassi et al., "Novel 1,4-benzothiazine derivatives: synthesis, crystal structure, and anti-bacterial properties," Research on Chemical Intermediates, vol. 42, no. 9, pp. 6845-6862, 2016.

[10] A. P. Rajput and S. A. Patil, "Synthesis, molecular docking and antimicrobial activity of 2-(3, 4-dihydro-3-oxo-2H-benzo [b] $[1,4]$ thiazin-2-yl) acetic acid esters," International Journal for Pharmaceutical Research Scholars, vol. 5, no. 2, pp. 97-106, 2016.

[11] V. Molteni, X. He, J. Nabakka et al., "Identification of novel potent bicyclic peptide deformylase inhibitors," Bioorganic \& Medicinal Chemistry Letters, vol. 14, no. 6, pp. 1477-1481, 2004.
[12] J. Gowda, A. M. A. Khader, B. Kalluraya, P. Shree, and A. R. Shabaraya, "Synthesis, characterization and pharmacological activity of 4-\{[1-substituted aminomethyl-4-arylideneamino-5-sulfanyl-4,5-dihydro-1H-1,2,4-triazol-3-yl] methyl\}-2H-1,4-benzothiazin-3(4H)-ones," European Journal of Medicinal Chemistry, vol. 46, no. 9, pp. 4100-4106, 2011.

[13] H. B. Borate, S. R. Maujan, S. P. Sawargave et al., "Fluconazole analogues containing $2 \mathrm{H}$-1,4-benzothiazin-3(4H)-one or $2 \mathrm{H}$ 1,4-benzoxazin-3(4H)-one moieties, a novel class of antiCandida agents," Bioorganic \& Medicinal Chemistry Letters, vol. 20, no. 2, pp. 722-725, 2010.

[14] J. Krapcho and C. F. Turk, "Substituted 2,3-Dihydro-1,5benzothiazepin-4(5H)-one and related compounds. II. A new class of Antidepressants1," Journal of Medicinal Chemistry, vol. 9, no. 2, pp. 191-195, 1966.

[15] T. Nagao, H. Narita, M. Sato, H. Nakajima, and A. Kiyomoto, "Development of diltiazem, a calcium antagonist: coronary vasodilating and antihypertensive actions," Clinical \& Experimental Hypertension Part A: Theory \& Practice, vol. 4, no. 1-2, pp. 285-296, 1982.

[16] E. Grossman, "Calcium antagonists," Progress in Cardiovascular Diseases, vol. 47, no. 1, pp. 34-57, 2004.

[17] P. Zhang, "Discovery of novel benzothiazepinones as irreversible covalent glycogen synthase kinase $3 \beta$ inhibitors for the treatment of acute promyelocytic leukemia," Journal of Medicinal Chemistry, vol. 64, no. 11, pp. 7341-7358, 2021.

[18] W. He, H. Togo, Y. Waki, and M. Yokoyama, "Application of the versatile character of the tellurium atom for the synthesis of C-nucleoside analogues via sugar tellurides," Journal of the Chemical Society, Perkin Transactions, vol. 1, no. 15, pp. 2425-2434, 1998.

[19] T. Junk, "Recent advances in the preparation and characterization of Te, N-containing heterocycles," in Tellurium: Properties, Uses and Research, D. Gray, Ed., Nova Science Publishers, New York, NY, USA, 2017.

[20] P. R. Mallikarachy, H. O. Brotherton, F. R. Fronczek, and T. Junk, "Facile access to organotellurium heterocycles by nitration of bis(3,5-dimethylphenyl) ditelluride," Journal of Heterocyclic Chemistry, vol. 42, no. 2, pp. 243-247, 2005.

[21] H. Sashida and H. Satoh, "Studies on tellurium-containing heterocycles. Part 22. Tellurazepine ring system: preparation of 1,5-benzotellurazepin-4-ones and their conversion into fully unsaturated 1,5-benzotellurazepines," Chemical and Pharmaceutical Bulletin, vol. 52, no. 4, pp. 413-417, 2004.

[22] S. Rudrawar, A. Kondaskar, and A. K. Chakraborti, "An efficient acid- and metal-free one-pot synthesis of benzothiazoles from carboxylic acids," Synthesis, vol. 15, pp. 2521-2526, 2005.

[23] P. Zhang, D. Ye, and Y. Chu, "An efficient one-pot procedure for the synthesis of 1,5-benzothiazepinones catalyzed by tetrabutylammonium fluoride (TBAF)," Tetrahedron Letters, vol. 57, no. 33, pp. 3743-3745, 2016.

[24] A. Kremer, A. Fermi, N. Biot, J. Wouters, and D. Bonifazi, "Supramolecular wiring of benzo-1,3-chalcogenazoles through programmed chalcogen bonding interactions," Chemistry - A European Journal, vol. 22, no. 22, pp. 56655675, 2016.

[25] T. Junk, N. C. McMullen, and F. R. Franczek, "Remarkably facile preparation of benzo-1,3-tellurazoles," Journal of Heterocyclic Chemistry, vol. 50, no. 1, pp. 120-124, 2013.

[26] W. H. H. Gunther: Oxachalcogenazole dyes and processes for their preparation, 1985.

[27] J. P. Myers, F. R. Fronczek, and T. Junk, "The first crystal structures of six- and seven-membered tellurium- and 
nitrogen-containing (Te-N) heterocycles: 2H-1,4-benzo-tellurazin-3 $(4 \mathrm{H})$-one and 2,3-dihydro-1,5-benzotellurazepin4(5H)-one," Acta Crystallographica Section C: Structural Chemistry, vol. 72, pp. 1-5, 2016.

[28] C. V. Deepu, M. Manjula, K. J. Pampa, D. G. Bhadregowda, and N. K. Lokanath, "7-Bromo-3,3-dibutyl-8-methoxy-2,3dihydro-1,5-benzothiazepin-4(5H)-one," Acta Crystallographica Section C: Structural Chemistry, vol. E69, p. 01129, 2013.

[29] A. Kremer, "Walking down the chalcogenic group of the periodic table: from singlet to triplet organic emitters," Chemistry - A European Journal, vol. 21, pp. 15377-15387, 2015. 